\title{
Offerings Dance as a Medium of Socializing Religious Values in the Catholic Church, Ganjuran, Yogyakarta
}

\author{
Merry Violyta Fransisca Pesulima, \\ Semarang State University, Indonesia.merry.pesulima.r@gmail.com. \\ Muhammad Jazuli, \\ Semarang State University, Indonesia.jazuli61@mail.unnes.ac.id \\ Tjetjep Rohendi Rohidi, \\ Semarang State University, Indonesia.trrohidi@mail.yahoo.com \\ Agus Cahyono \\ Semarang State University, Indonesia.aguscahyono@mail.unnes.ac.id
}

\begin{abstract}
The offering dance also known as standard dance is a religious or ritual ceremony comprising freedom of creation. Therefore, this study aims to identify the offering dance as a means of socializing religious values in the Catholic Church, Ganjuran, Yogyakarta. This is qualitative research with anthropological and art approaches. Data were collected through observation, interviews, and documents. The obtained data were analyzed through data reduction, presentation, and verification procedures. Furthermore, the triangulation of data sources, methods, and theories was used to determine their validity. The values of religiosity associated with offering dance used Bouman's analysis to determine the values considered sacred by the community. These values are used as guidelines and further analyzed based on Maclever's socialization analysis, which is a process that individuals go through to learn the norms, values, roles, and all other requirements needed to enable effective participation in social life. The results showed that the offering dance used as a means of socialization comprises educational, tolerance, moral education, culture, aesthetics, and social solidarity values. In addition, the findings also showed that the offering dance has been passed down from generation to generation with symbols capable of indirectly affecting the condition of the congregation and society.
\end{abstract}

Keywords: Offerings Dance, Socialization, and Religious Values

\section{INTRODUCTION}

The development of information and communication technology massively corre-lates to the increase in digital data. We live in a world where vast amounts of data are collected every day. Analyzing the data is an essential requirement. One of the digital data is publication data. Data can be collected and explored using a technique called data mining. Data mining is the process of finding interesting patterns and knowledge from a large amount of data. Data sources can include databases, data warehouses, the Web, other information repositories, or data that is streamed to the system dy-namically (Han, J., Kamber, M., \& Pei, J. ,2012). In this study, researchers conducted educational technology research data mining.

Changes in arts are influenced by various factors, such as education, social, economy, politics, religion, and culture. According to Suciningsih (2012), the arrival of Indians, Arabs, Africans, and Europeans led to the introduction of various cultural dances on the island of Java. One of the new dance steps created due to religiosity in the Catholic Church, located in Ganjuran, Yogyakarta is the "Offering Dance" which has undergone many changes from elements of motion, costumes, make-up, to floor patterns.

This is a new dance type, which acts as the basic concept of classical Javanese dance developed in accordance with the conditions of the times, where the movements have been given new Indonesian elements and a more modern style. The associated offering dance that comes from the $1950 \mathrm{~s}$ and above is categorized as relatively young, therefore those born after the development of the traditional dance have witnessed various forms of change (Nalan, 1996: 11). This offering dance is called an art field, with freedom in creation. It means that this dance is not standard, rather it is a special religious ritual.

The offering dance has been around since 1992 and was created at the request of Pastor Romo Utomo (1929-2020). The pastor expected a traditional dance to indicate gratitude, which was included in the Liturgy of the Great Kirab Procession of the Most Holy Sacrament and functioned as a religious ceremony dance or ritual. Until now, the Offering Dance presentation was part of a series of procedures standardized in the Liturgy of the Great Sacred Sacrament Procession of the Catholic Church in Sumbermulyo Village, Bambanglipuro, Bantul, Yogyakarta. According to Maclever (2013), socialization is a process through which individuals learn the norms, values, roles, and all other requirements needed to enable effective social life participation. 
It comprises various societal benefits for individuals and society. For individuals, it functions as a guide for learning to know, adapting to their environment, and planting good values, norms, and social structures from one generation to another within the community. Meanwhile, for society, it preserves, disseminates, passes down values, norms and beliefs. In this learning process, individuals are opportune to know the real social and physical environment. Furthermore, there is an adaptation in the socialization process, which enables them to adapt to the environment comprising regulatory rules or norms. This means that people that enter the environment need to adjust to the applicable rules with the ability to bind every individual in society (Khairuddin, 1985). Based on the literature above, it is concluded that socialization is a process comprising a community's culture, with interactions between individuals to determine their behavior. Therefore, it helps the environment determine the system of life, economy, and culture as the essential link in the chain and enable each individual and other social groups to participate directly.

\section{METHODOLOGY}

This research uses the qualitative method with an interdisciplinary and anthropological approach. The anthropological approach is used to reveal and analyze culture and dance movements at the Sacred Heart of Jesus Catholic Church, Ganjuran Yogyakarta. The qualitative method is designed based on several scientific disciplines starting from the main approach, namely dance in a cultural event. Meanwhile, the anthropological approach to art is carried out to determine the culture, religiosity, and dance in the environment and society. Therefore, the form of culture of dance work is related to faith, belief, and spirituality.

Data collection techniques were carried out through observation, interviews, and documentation. Observations were made to obtain information through the processes carried out in the training and performance of liturgical activities. The offering dance was utilized as a means of media socialization in instilling religious values. Furthermore, interviews were conducted with the head of the Sacred Heart of Jesus Catholic Church, Ganjuran Yogyakarta, as well as community figures directly related to the church. Through documentation, photographs, videos, and documents related to the offering dance were obtained. The triangulation techniques were used for data validity in three forms, namely (1) data triangulation, (2) source triangulation, and (3) method triangulation. The source triangulation method was used to test the validity of the data from several areas. In addition, source validity was performed by comparing the observed data with the related documents' interview and contents. Meanwhile, the triangulation method was achieved by making use of various theories, methods, and techniques to analyze the same problem. Data analysis techniques are based on Miles and Huberman's analysis, consisting of data reduction, presentation, and verification.

\section{FINDINGS / RESULTS}

Indonesia, with its cultural diversity, comprises numerous dance forms from each region. Dance in its context has several elements of movement that appear as symbols, including differences in the principles of beauty from art, which is influenced by the presence of wirama (rhythm), wiraga (body movement), and wirasa (feeling) techniques (I Wayan Dibia, 1996).

The offering dance is a traditional Javanese dance that is very basic and inherent in people's lives. In this dance, there are elements that need to be considered, both in terms of movement, the place of performance, musical accompaniment, make-up, fashion, and lighting and sound system. Therefore, a show tends to look harmonious because it is in accordance with local wisdom. The offering dance is religious in nature which functions to accompany the entire process of a series of religious activities. It is considered a means of interacting with the Creator and directly socializing in people's lives, and having religious values.

The offerings dance as a ritual art has unique characteristics such as a). the venue chosen needs to be clean and sacred, b). the time and day act as determinants during the show, c). program supporters need to have experienced self-purification, d). offerings are a major factor in every show, and e). the use of clothing that characterizes the local area (Soedarsono, 2002).

Dance as an educational means is used to develop aesthetic sensitivity through appreciative activities and creative work experiences. Appreciative activities direct the interpretation of a dance work in order to have the ability to enjoy, appreciate the types the function properly and positively. Religiosity is considered formal and institutional because it reflects a commitment to belief in practices according to a particular religion. Multazam 
(2005) stated that it is a form of the human relationship with its Creator through internalized religious teachings that are reflected in their daily attitudes and behavior. Religiosity values invite someone to do good, such as human relations with God, fellow humans, nature or the environment, as well as religious education. It is felt in the attitude of the soul's depth, which is not very visible, rather it has a deep meaning, such as sincerity in appreciating differences and a great sense of responsibility. Religious attitudes are also described and expressed when praying, surrendering to the Divine, asking for forgiveness, and always forgiving others. It refers to conscience, and a strong human taste, which was inseparable. Humaidi and Fatmawati (2019) reported that religiosity is the appreciation and implementation of religious teachings in everyday life. In line with this, Kuliyatun (2019) stated that it is the highest absolute and eternal spiritual value from human beliefs. Religious values are cultural elements inherent in people's lives through traditional activities and religious ceremonies originating from human beliefs. According to Mulyadi (2018), it comprises values that originate from religion or the highest truth from God, which is very broad in scope and regulates all aspects of human life. Religious values become a way of life that influences one's behavior in everyday life.

There are several values associated with offering dance to socialize religious values in the Ganjuran Church. One of such values is the w meaning of a dance movement that symbolizes praying and praising God with an activity process that prioritizes religious values in promoting love for others. The religious values visualized in motion with meaning are also seen as an attitude of thanking God for all the gifts given. This is because there is a soul that always prioritizes virtue by giving thanks to God Almighty. In this traditional offering dance, the religious values are performed by female dancers in a calmer feeling atmosphere, thereby making them more aware of everything given by God, without being arrogant and proud. The offering dance as a ritual art has unique characteristics. It contains many religious values such as tolerance, morals, aesthetics, i.e, the beauty of the dance itself, and cultural education.

\section{CONCLUSION}

Based on the above discussion, it can be concluded that offerings dance as a means of socializing religious values consists of love, joy, peace, patience, kindness, loyalty, gentleness, and self-control. Its value of religiosity at the Ganjuran Church is also numerous and is reflected in the process associated with traditional dance. One of such religious meaning symbolizes praying and praising God while prioritizing and promoting love for one another. The religious values visualized in motion and the meaning contained in the offering dance = prioritizes virtue by giving thanks to God Almighty for all the gifts.

The value of tolerance has three aspects, namely peace, respect for differences and individuals, as well as awareness. Peace is also formed when local residents seek mutual help, respect among fellow congregations, and respect differences in opinion. Meanwhile, tolerance is formed from individuals' awareness in their environment, making peace between groups by respecting differences in their respective self-awareness. The value of moral education in offering dance needs to be considered noble artistic in traditional dances without a moral order involving humans as God's creatures.

Furthermore, the value of cultural education in offering dance comprises attitudes, behavior, and beliefs that are embedded in acting and behaving. The symbols in the offering dance are manifested in the dancers' movements and have meaning. Attitudes or behavior in cultural values is reflected in everyday life of Ganjuran Church members. The Javanese attitude symbolized in the dance movements reflects their polite behavior towards their parents and elders. Activities that contain values of daily behavior in the community and environment reflect on members' social norms and their ability to behave well through joint activities, namely art, especially dance offerings comprising cultural education values.

Regarding the value of aesthetic education, activities related to art in the process of offering dance are exemplified to help appreciate the meaning of self-offering by people. The aesthetic value of traditional dance offerings contained in Javanese dance has the harmony of faith and piety of the people. Art is visualized from the connoisseur by paying attention to the inherent religious values.

\section{REFERENCES}

1. Adimurti, J. T. (2005). Inculturation of Church Music in Toba and Simalungun Bataks. Harmonia: Journal of Knowledge and Art Thought. 
2. Agbo, B. N. (2017). Inculturation of Liturgical Music in the Roman Catholic Church of Igbo Land: A Compositional Study. Journal of Global Catholicism,

3. Ahmad, Abu, Drs. H. (2007). Sociology of Education. Jakarta. PT.

4. Agnieška JUZEFOVIČ, Faculty of Creative Industries, Department of Philosophy and Political Theory, Sauletekio al. 11, LT-10223 Vilnius, Lithuania, Creativity And Aesthetic Applied To Ecological Education.

5. Asdi Mahasatya Education and Cultural Change. (2013). From Culture / [accessed 09 September 14].

6. Augustine. (2011). Singing the Mass: Liturgical Music as Participation in Christ. Adoremus Bulletin. Retrieved from http://www.adoremus.org/0512SingingtheMass.html

7. Allyson Donoso Katherin Ortega Universidad Central de Chile, Chile, Patricio A. Pino Castillo Facultad de Educación, Universidad Santo Tomás Chile, 2020, Understanding the Meaning of Multicultural Collaboration in a Public - School EFL Class.

8. Ardiansyah, A., Kamaludin, \& Argubi, A. H. (2017). Carrying Capacity and Community Participation in Tourism Activities in Lakey Tourism Object, Dompu Regency, West Nusa Tenggara. Journal of GaneC Swara.

9. Abdullah Nashih Ulwan, Child Education Guidelines in Islam, Volume I, (Semarang: Asy Syifa, tth).Setyoningrum, Y. (2008). Overview of the Inculturation of Catholicism with Javanese Culture in Catholic Church Buildings in the Dutch Colonial Period (Thesis). Maranatha Christian University, Bandung.

10. Bakok, Y. D. B. (2013). Inculturative Liturgical Music at Yogyakarta Ganjuran Church.

11. Berinai, J. (2014). Liturgical Inculturation in Anglican Worship in Light (Thesis). Middlesex University, London.

12. Bezuidenhoudt, J. (2010). Liturgy and Spirituality in The Ecumenical Movement: A SystematicTheological Evaluation (Dissertation). University of Stellenbosch, Stellenbosch.

13. Cowden, S. A. (2015). Liturgical Inculturation among Baptists in the United States (Thesis). Baylor University, Texas.

14. Koentjaranigrat.(1990).Introduction to Anthropology. Jakarta; Rineka Cipta.

15. Kustanto, J.B. Day. (1989).Inculturation of Catholic Religion in Javanese Culture. Yogyakarta: Yogyakarta Pastoral Center.

16. H.A.R. Tilar, (2000). Cultural Education and Indonesian Civil Society.Bandung: Youth Rosda Karya

17. Hadi, Sumandiyo. (2006). Art in Religious Rituals. Yogyakarta: Reader.

18. Suciati, Qudus International Journal of Islamic Studies Volume 4, Issue 2, August 2016, Islamic Education of Children With Parents As Indonesian Migrant Workers (Case Study in Karangwotan Village, Pati, Central Java.)

19. Schineller, Peter (1990), A Handbook on Inculturation, New York : Paulist Press.

20. Mustofa, (2013). Inkulturasi dalam Relief Gereja Hati Kudus Tuhan Yesus Ganjuran Yogyakarta, Skripsi UIN Kalijaga, Yogyakarta.

21. Pedro PALOS-SANCHEZ, Creativity studies,International University of La Rioja, Faculty of Business and Communication, Department of Business Organization, Marketing and Market Research, Av. de la Paz, 137, 26006 Logroño, Spain, How Attitudes, Vision and Ability To Capture Opportunities Affect Startups' Business Creativity.

22. Wuradji, Dr. M.S. (1988). Sociology of Education. Jakarta. Ministry of Education and Culture, Directorate General of Higher Education Project for the Development of Educational Workforce Institutions. 